\title{
THE ABUSE OF RIGTS IN TAX AND ADMINISTRATIVE LAW
}

\author{
Martina Radkova \\ Faculty of Law, Palacký University Olomouc, Czech Republic \\ email: martina.radkova@seznam.cz
}

RADKOVA, Martina. The Abuse of Rigts in Tax and Administrative Law International and Comparative Law Review, 2011, Vol. 11, No. 1, pp. 125-144. DOI: 10.1515/iclr-2016-0100.

Abstract: Aim of this article is to point out the recent development of the principle of abuse of rights in tax and administrative law. Subject of this article is not abuse of discretion, abuse of rule of law, abuse of power or eventual other abuses. Although abuse of rights is traditionally category of private law, we could observe application of this institute in European public law including the Czech public law.

Keywords: abuse of law, abuse of rights, contra legem, in fraudem legis, dissimulation, principles, principle-based legislation, intention

\section{Introduction}

Aim of this article is to point out the recent development of the principle of abuse of rights in tax and administrative law. Subject of this article is not abuse of discretion, abuse of rule of law, abuse of power or eventual other abuses. Although abuse of rights is traditionally category of private law, we could observe application of this institute in European public law including the Czech public law.

Historically, abuse of rights had been observed in the times of Roman law and firstly was connected with property law. Then it spread further in the whole private law. Although I have not found sources describing abuse of law in tax law or other branches of public law in history, I am convinced that reason for this fact is only absence of reference. If taxes and tax law exist as long as our society, there had to be attempts to reduce taxes always. While describing abuse of law and comparing various attitudes, differences between legal systems and national jurisdictions are important. It is to note one more fact: tax law is in the Czech Republic regarded as part of public law, contrary to some Western jurisdictions. Moreover, according to some opinions, common law has no general doctrine of abuse of law. 
Definition of abuse of rights does not exist in the Czech law and neither in many other countries. Abuse of rights is connected with subjective rights. Several authors defined abuse of rights, their papers will be reffered also later. According to Paul Lasok „abuse“ is rhetorical device whose purpose is to express disagreement with particular, but lawful, exercise of rights. French courts developed concept of abuse of rights to cope with misuses of unqualified rights. According Hui Ling McCarthy (analysing abuse of rights in connection with VAT planning - see further reference) there is still no precise definition of "abuse of rights". Instead there is an evolving body of EU case law, formulating the circumstances in which abuse may be present. In the absence of national abuse provisions prescribing those circumstances, the purpose of the doctrine is to catch cases where either a person is attempting to rely on a European legal right to circumvent or displace national law, or a person is looking to gain a financial or other advantage by way of an abusive use of Community law. Czech author Zdeněk Pulkrábek refers to French definition which construes abuse of law broadly and regards intent to cause somebody harm as a feature of abuse of law. According to other opinion the attribute is illegal caused behaviour which differs from acting of ordinary, reasonable and vigilant individual. His third quotation and criterion of abuse of law is economic and social purpose of law. What all definitions have in common, is purpose or intent to harm other person (or society) and get an advantage. The way how to reach this is related to creation of situation which differs from original one, that means we see a reconstruction or simmulation. The line between legal and illegal behaviour is very difficult to find since there are legal ways how to reduce tax base (or observe other rules both in letter and spirit).

To describe theory of abuse of rights (or law), I refer to monography of Czech author Zdeněk Pulkrábek. ${ }^{1}$ Although this work was done for private (civil) law, some of thoughts of author can be useful. Abuse of rights relates to exercise of rights (also filing a suit could be considered as abuse of rights). Pulkrábek defines abuse of law as such a relying on the law which is somehow faulty. Means to prevent defectiveness of that is to apply the principle of abuse of law. Defective can be relying on the law, result of exercise of rights or the law itself. Interpretation of the terms mentioned above is related to values and principles applied by interpreter. As a ground for interpretation serves idea of purpose of law, requirement for law to be balanced, harmonious and moral, ethical and fair. Purpose of law is fundamental for law and constitutionally based in preambule of the Czech constitution. Purpose of law is to provide benefits for entitled persons, to satisfy their needs and interests and the aims of this stipulations are fairness, justice, equity. The abuse of law should impact firstly on the law itself (derogation), secondly on behaviour of person entitled of rights and person obliged to do something (regulation) and thirdly on enforcement of the law. Abuse of rights is coupled with behaviour of entitled person or with behaviour of person

1 Zdeněk Pulkrábek: Zákaz zneužití práva v rozporu s jeho účelem. Eurolex Bohemia, Praha 2007. ISBN 978-80-86861-93-7 (in Czech language) 
obliged to do something, with their position, with unilateral act or other acts (objection, protest, notice, dismissal, motion, action etc.). Essential is to answer what constitutes abuse of rights and how is the principle to be applied. Abused can be only rights - where is not right (law), there is no abuse. The content of the law can be recognized solely under particular circumstances, abuse of law is not abstract category. Derogation of abused rights could be absolute or partial. Effects of derogation of abused right are ex nunc or ex tunc - it depends on the fact if the abuse there was from the beginning of the transaction. The act arised from abused right is null and void and the court must take it into account ex offo.

Pulkrábek distinguishes four forms of abuse of law:

1. entitled person intends to harm other; damage could be any detriment or disadvantage,

2. entitled person can follow other purpose than that which is defined by the law,

3. entitled person is mistaken and supposes benefit,

4. entitled person is only stubborn, the aim is solely exercise of right, not the consequences of that exercise.

Pulkrábek believes that also negligible, very small benefit should be protected. Author quotes Swiss author H. Merz who regards as general principle obligation to exercise rights in the most modest manner. In opinion of Pulkrábek, defectiveness in abuse of law is based also on other factors (different from the contradiction to purpose of law): that is contradiction to good moral, serious contradiction between benefit and harm, exercise of rights is unscrupulous to interests of obliged person, contradiction in own behaviour and conflict with public interest. Abuse of law relates both to objective contradiction to purpose of law (connected to benefit) and subjective contradiction to purpose of law (connected to intention of acting person). According to author of monography, abuse can concern any right. Contrary to principle of abuse of rights there is requirement of legal certainty.

Comparing above mentioned ideas with fundamental principles of public law, several issues emerge. Firstly, accordance with public interest is prescribed by the Czech Administrative Procedure Code. Fundamental principles are elaborated in detail in particular provisions in administrative law. Application of law deals more with particular breach of law then solely with breach of principle, both in administrative and judicial procedures. To reject the right (application, request) only on the basis of contradiction with public interest is very rare and usually it is related to application of abuse of law or circumvention of law. On the other hand, to grant right solely on the basis of application of principle has been observed several times (it is to note that it was chiefly in judicial practice). 
There are still other concepts similar to abuse of law or other terms for same or similar situations. To name some of them, there is malice, false intent, absence of good faith, bullying, harassment. Especially in tax law is to refer to anti-avoidance rule (which difers from evasion). Abused can be both substantive and process law.

Abuse of law is associated fundamentally with interpretation of law. Textualists and contextualists discuss the issue, we can take into account natural justice and positivism etc. Some authors speak about abuse of interpretation. ${ }^{2}$ According to Steven Dean and Lawrence Solan ${ }^{3}$,the goal of statutory interpretation is to find and enforce the intended meaning of the legislature and that the best evidence of this intent is the language of the statute". Tax shelters take advantage of the flexibility of words and of the gaps in legislation. Authors remark on recent use of rule of lenity by courts. According to this rule (originated in penal law) statutes should be strictly construed against the government. Lexis survey found that federal and state courts used the word "intent" in their decisions 60.000 times in ten years period. Some courts found intent of legislator in the language of the statute, some outside of it. According to Justice Scalia meaning can be understood in accord with context and ordinary usage of the language (for this the whole Congress voted) and as compatible with surrounding body of law, he would not permit to examine any historical and legislative material. He does not regard intent of legislator as the proper criterion of the law. Authors believe that textualists consider legislative history as unreliable and weak argument and aggrandizing the role of congressional committees. The lenity principle has been used both in civil and criminal cases. The U. S. Supreme Court applied it in civil cases where the statute in question had both civil and criminal remedies. This could be inspirative also for the Czech law. Authors of the paper do not believe that applying lenity rule to Tax Code is likely and that it would have good result. In fact, lenity rule was articulated by Chief Justice John Marshall in United States v. Fischer in 1805. Due to interpretation government was given priority over other creditors. Practically, where administrative agencies are entitled to enforce law bouth through civil courts and criminal law, they become more agressive over time. Tax fraud has a strong mens rea (quilty mind) element. This rule then can resolve an ambiguity. These tools come into operation not in the beginning of their process but in the end of construing. This is the function of judiciary and of course also of tax administration. Although judges use reasonableness as key principle and when can not determine intent of the legislature, they resolve disputes in favor of taxpayers, result is uncertainty. Also sta-

2 Terezie Smejkalová: Zneužití výkladu práva in COFOLA 2010: the Conference Proceedings, 1. edition. Brno : Masaryk University, 2010, ISBN 978-80-210-5151-5, http://www. law.muni.cz/sborniky/cofola2010/files/zneuziti/Smejkalova_Terezie_1641_.pdf, seen 29. 10. 2011

3 Dean, Steven and Solan, Lawrence M., Tax Shelters and the Code: Navigating between Text and Intent. Virginia Tax Review, Vol. 26, pp. 879-904, 2007; Brooklyn Law School, Legal Studies Paper No. 69. Available at SSRN: http://ssrn.com/abstract=958720 
tistics does not help: victories of government and taxpayers are almost the same. As a solution authors do not see aggressive purposive aproach (it is not credible) but think that anti-abuse doctrines are important, regardless if they are established in statutes or judicially. In fact they permit courts to focus on statute's purpose without looking outside its language.

Gianluigi Palombella ${ }^{4}$ considers abuse of rights from the point of view of rule of law. Author regards using abuse of law as the resistance of formal principles as a shield to hide objectives incompatible with the legal order and then quotes Justice Antonin Scalia's question whether to decide case on the basis of „totality of factual circumstances" or to define general rule.

\section{European law and abuse of rights}

The abuse of rights in European law shines through all this paper. I would like to highlight few of best analysis on this topic. The paper devoted to origins and history of the principle was elaborated by Paul Lasok. ${ }^{5}$ He splits up the situations of abuse of EC law into abuse of 1. private persons and 2. member states and further in three contexts:

1. reliance upon EC law which results in abuse of domestic law,

2. application of EC law leads to extracting (financial) benefit from the Community,

3. application of harmonised legislation which does not contain explicitly anti-abuse rule.

None of these situations has a character of dishonesty or fraud. To define the terms due to linguistic differences, author divides: „right“ is subjective and "law" is objective. Also Lasok sees the responsibility of legislature to define what is "right“ and what is „wrong“. And also points out the difference between legislative approach (that means if legislature defines abuse of law) and jurisprudential approach (technically imposing limits on the exersice of lawful right). Lasok compares - in common law of England and Wales non-existing - doctrine of abuse of law to principles of equity and in European law with principle if proportionality. Abuse of law is discussed since attempts to avoid an abligation mean putting it in another way, to create situation that falls outside the scope of the obligation. This resulted in need for more sophisticated approach to reddress the situation and use of more complex remedy as liberty or freedom are abused. Author refers to raids on the revenue and differences on just minimising tax liability (footnote 14), to the cases where existence of the concept of abuse of law

4 Gianluigi Palombella. „THE ABUSE OF RIGHTS AND THE RULE OF LAW“ THE DARK SIDE OF FUNDAMENTAL RIGHTS. Ed. ANDRAS SAJO. LEIDEN: ELEVEN PUBLISHER, 2006. Available at: http://works.bepress.com/gianluigi_palombella/1

5 Paul Lasok: Abuse of Rights in EC Law - Origins and History. http://www.monckton.com/ docs/library/AbuseRightsJune06PL.pdf, seen 12. 10. 2011 
was denied by Denmark, Ireland and the United Kingdom in 1998 (case Kefalas - footnote 23, see this paper for further reference) and abuse of power by the States (misuse of power and acting outside the scope of power which is extremely difficult to recognize in public law). As to abuse of rights Lasok highlights that intensity of disparity in the situation with abuse of rights must be so great that the only sensible explanation for the exercise of the right is the predominant purpose to cause harm to another. In this point I must refer to other concepts where sufficient is causing harm, regardless of intensity of the act and other reasons of the act. Lasok came to conclusions that:

1. Distinction between definition of right and abuse of right is tenuous, abuse of rights is better expressed with particular types of limitation of its exercise, what matters is not legal nature of origin of limitation but its rationale.

2. There is no reason why public bodies should be in different legal position - the other concept is misuse of power rather than right, differences in concepts are rather material than formal.

3. Abuse of right is based on the end contrary of purpose served by the right or its excessive or disproportionate manner.

4. Matterial differences in particular cases must be emphasized.

5. The concept of abuse of rights is not suited to converse, that is, the conduct of harmed persons is not object of this concept, certainly in public law.

In case C-367/96 Kefalas v. Greece, the ECJ was asked whether national court should apply domestic definiton of abuse of right or of Community. The ECJ held that a domestic anti-abuse rule can, under Community law, be applied for the purpose of assessing whether or not the exercise of a right under EC law is "abusive" but "the application of such a national rule must not prejudice the full effect and uniform application of Community law in the Member States..." and that "it is not open to national courts, when assessing the exercise of a right arising from a provision of Community law, to alter the scope of that provision or to compromise the objectives pursued by it". According to Lasok the substantive elements of the principle are:

1. reliance on a provision of EC law,

2. the derivation of an improper advantage to the detriment of another, and

3. the advantage must be manifestly contrary to the objective of the provision relied upon. There is also an evidential requirement: the evidence of abuse must be "sufficiently telling".

In Case C-373/97 Diamantis v. Greece the ECJ refined the test by objective evidence: "first, a combination of objective circumstances in which, despite formal 
observance of the conditions laid down by the Community rules, the purpose of the rules has not been achieved" and "second, a subjective element consisting in the intention to obtain an advantage from the Community rules by creating artificially the conditions laid down for obtaining it".

In Case C-255/02 Halifax plc and others v Commissioners of Customs and Excise abusive practice is described as "transactions carried out not in the context of normal commercial operations, but solely for the purpose of wrongfully obtaining advantages provided for by Community law". The ECJ went on to hold: “...an abusive practice can be found to exist only if, first, the transactions concerned, notwithstanding formal application of the conditions laid down by the relevant provisions of [EC law] and the national legislation transposing it, result in the accrual of a tax advantage the grant of which would be contrary to the purpose of those provisions. Second, it must also be apparent from a number of objective factors that the essential aim of the transactions concerned is to obtain a tax advantage". Hui Ling McCarthy ${ }^{6}$ points out that the ECJ was clear that the doctrine was not a general anti-avoidance principle, nor could it be used to invalidate all structures where tax mitigation comprised merely one of a number of drivers. Indeed, the doctrine does not operate in a vacuum - it must be considered in conjunction with other well-established principles of Community law, such as legal certainty and fiscal neutrality.

Lasok regards reliance on EC law to abuse domestic law as real problem and seen from the perspective of domestic law, EC law is nothing other than vast avoidance exercise. Author illustrates this on several examples (reimports, abuse of freedom of establishment in order to circumvent the minimum capital requirements in domestic country etc.). Application of EC law does not necessarily mean that domestic concept of abuse of law can not be applied at all but it must be in compliance with EC law.

The third group of abuses deals with obtaining benefit from EC by direct application of EC provisions. There the ECJ held again as necessary conditions for abuse of law meeting both objective and subjective criteria. Anti-avoidance or anti-abuse rule is set up in article 4(3) of Council Regulation No. 2988/95. Definiton labels abusive acts as acts established to have as their purpose the obtaining of an advantage contrary to the objectives of Community law by artificially creating the conditions required for obtaining that advantage which would result in either the failure to obtain the advantage or, if it had been obtained, the withdrawal of the advantage.

6 HUI LING MCCARTHY: ABUSE OF RIGHTS - THE EFFECT OF THE DOCTRINE ON VAT PLANNING. From the British Tax Review published by Sweet \& Maxwell in May 2007 - [2007] BTR No.2 160. http://www.taxbar.com/documents/Abuse_of_Rights_Doctrine_on_VAT_Planning_Hui_Ling_McCarthy.pdf, seen 29.10. 2011 
Lasok worries if the implication of Halifax case which contains best known concept of abuse and harmonised anti-abuse rule, allows to apply domestic antiabuse rules in future.

Abuse of EC rules by memeber states is indirectly incorporated in Article 30 of the EC Treaty.

As to examination of intention, quide was offered by the ECJ on 12.1.2006 in joined Cases Optigen Ltd (C-354/03), Fulcrum Electronics Ltd (C-355/03) a Bond House Systems Ltd (C-484/03) v. Commissioners of Customs \& Excise. The court held that: „Transactions ... which are not themselves vitiated by value added tax fraud, constitute supplies of goods or services effected by a taxable person acting as such and an economic activity within the meaning of Articles 2(1), 4 and 5(1) of Sixth Council Directive 77/388/EEC of 17 May 1977 on the harmonisation of the laws of the Member States relating to turnover taxes - Common system of value added tax: uniform basis of assessment, as amended by Council Directive 95/7/ EC of 10 April 1995, where they fulfil the objective criteria on which the definitions of those terms are based, regardless of the intention of a trader other than the taxable person concerned involved in the same chain of supply and/or the possible fraudulent nature of another transaction in the chain, prior or subsequent to the transaction carried out by that taxable person, of which that taxable person had no knowledge and no means of knowledge. The right to deduct input value added tax of a taxable person who carries out such transactions cannot be affected by the fact that in the chain of supply of which those transactions form part another prior or subsequent transaction is vitiated by value added tax fraud, without that taxable person knowing or having any means of knowing."

Another case (Weald Leasing Limited v. the Commissioners for Her Majesty's Revenue and Customs, C-103/09) deals with abusive practice in connection with involvement of third party in the transaction. The ECJ held that „1) the tax advantage accruing from an undertaking's recourse to asset leasing transactions, such as those at issue in the main proceedings, instead of the outright purchase of those assets, does not constitute a tax advantage the grant of which would be contrary to the purpose of the relevant provisions of Sixth Council Directive 77/388/EEC of 17 May 1977 on the harmonisation of the laws of the Member States relating to turnover taxes - Common system of value added tax: uniform basis of assessment, as amended by Council Directive 95/7/EC of 10 April 1995, and of the national legislation transposing it, provided that the contractual terms of those transactions, particularly those concerned with setting the level of rentals, correspond to arm's length terms and that the involvement of an intermediate third party company in those transactions is not such as to preclude the application of those provisions, a matter which it is for the national court to determine. The fact that the undertaking does not engage in leasing transactions in the context of its normal commercial operations is irrelevant in that regard. 2) If certain contractual terms of the leasing transactions at issue in the main proceedings, and/or the intervention of an inter- 
mediate third party company in those transactions, constituted an abusive practice, those transactions must be redefined so as to re-establish the situation that would have prevailed in the absence of the elements of those contractual terms which were abusive and/or in the absence of the intervention of that company. "The issue is whether the courts of all member states would apply rule stipulated in the decision in the correct fashion in similar cases.

\section{Tax law and abuse of rights}

As I mentioned above, tax law is old as society and therefore intention to reduce tax burden is old alike. Serious reference is observed in modern history. Especially recently, there is concern on issues of abuse of tax law. Roots of this matter must be seen in economic and social reality. As to legal point of view, concept of abuse of law or similar concept such as sham doctrine, fraus legis doctrine or doctrine „substance over form“" (dissimulation doctrine) are observed in many jurisdictions, regardless of their content.

In focused comparison ${ }^{7}$ with illustrative case law examples authors concluded that tax avoidance is problem for all countries. They start with drawing the line between „mitigation“ as legal reducing one's tax, „evasion“ as lying about one's income and "avoidance" which is between two and means contriving artificial transactions to reduce tax. According authors this is description rather then definition. Main authors with Svenja Brandt explain German civil law doctrine of abuse of right. Its underlying principle is good faith, stipulated in Para. 242 of German Civil Code (Mißbrauchsverbot), and broadly judicially interpreted (original Schikaneverbot according to Para. 226 BGB has been seldom applied). Four categories of abuse of rights are:

1. the prohibition on inconsistent behaviour;

2. the prohibition on exercising rights which, though valid, were fraudulently acquired;

3. the prohibition on making a claim where what is claimed would have to be given back immediately;

4. the suspension of rights that were not exercised within a reasonable time, even if they have not legally expired.

What is notewhorthy, this concept is fully applied to German procedural, public and tax law. Furthermore, German Federal Code of Tax Procedure in Para. 42 sets down general anti-avoidance rule. It disallows the tax effects of any legal arrangement that constitutes an abuse of rights. Taxpayers may not arrange

7 John Prebble and Zoë Prebble and others: Comparing the General Anti-Avoidance Rule of Income Tax Law with the Civil Law Doctrine of Abuse of Law. 2008. Bulletin for International Taxation. s. 151-170 Zdroj: http://papers.ssrn.com/sol3/papers.cfm?abstract_ id $=1479931$ 
their affairs to manipulate or distort the economic reality of a transaction. Such manipulation or distortion is tax avoidance and is countered by the doctrine of Rechtsmissbrauch or, in the context of tax law, by the more specific concept of abuse of possible legal arrangements (Gestaltungsmissbrauch). German courts interpret this abuse according to four elements:

1. legal arrangement must be inadequate,

2. arrangement must have affect of reducing tax,

3. there must be important grounds for reasonabless and justification for contrary arrangement by non-economic or other considerations,

4. there must be subjective element.

Test of inadequacy asks whether an objective third party, in the same circumstances and with the same economic purpose as the taxpayer, would have proceeded as the taxpayer did.

Example of Croatia shows that this country has no anti-avoidance provisions and deals only with sham doctrine (above all, Croatia is reportedly focused on tax evasion). Interestingly, this doctrine has never been used (I remind that the article was published in 2008). Sham is transaction which is not real. Authors prefer as a model Hungary which is only country in Eastern Europe that enacted general anti-avodance rule (Para. 1/7 of Tax Administration Act). It is based on abuse of law or fraus legis doctrine, similar to Germany's model. Hungary's antiavoidance rule provides that transaction whose purpose is to avoid tax would be taxed according to its economic base (we can call it also doctrine „substance over form"). By the way, as I mention in more detailed manner for the Czech Republic later, information that Hungary is sole Eastern country with this rule is not correct.

New Zealand anti-avoidance rule is similar to other, Income Tax Law adds that purpose or effect of avoidance is not merely incidental. Tax avoidance agreement is void against Commisioner. Avoidance arrangement can rest upon agreement, plan, contract or understanding, including steps and transactions. Difference between New Zealand and Australia are not in legal definitions but in judicial interpretation and application. New Zealand does not rely only on the result that tax was reduced. First dichotomy is between legal form and legal substance and the second on legal and economic substance. The tax avoidance test is objective and examines whether the parties would have entered into the transaction even in the absence of the tax advantage. For example in the Case V20 (dentist left partnership and established a trading trust) Justice Barber held that there was no tax avoidance since the tax advantage was incidental to the transaction's commercially valid chief objectives to protect assets and limit lability and tax savings were minor. Nevertheless, the same dentist in the 1996 income year was judged in the Case W33 and the court concluded that large tax savings of the 
dentist were not merely incidental. Third method refers to the scheme and purpose of the Income Tax Act 2007 (intention of the Parliament). As tax avoidance is regarded inserting a related entity into a transaction in order to create artificial deductions (see contrary decision of ECJ mentioned later).

Australia is an example of activist judiciary and efforts of government to overturn it (reported in 2008). Courts use mainly two interpretative techniques: predication test (similar to New Zealand doctrine described above) and choice principle which was developed by High Court of Australia to protect general provisions of tax law rather than to deny taxpayers the rights to choose between alternatives open to them by that code (e.g. taxpayer can choose legal form but a university can not use tax advantage designed for farming business $\left.{ }^{8}\right)$. Australia's current regime of anti-avoidance rule has three components:

1. taxpayer must obtain benefit,

2. the benefit must be from scheme, and

3. the scheme must have been entered into by a taxpayer for the sole purpose of obtaining the tax benefit.

The main focus is on dominant purpose. Contrary to New Zealand's test which is objective, the Australian test is subjective and less general and uncertain. The latter is most controversial in purpose test and is interpreted rather narrowly. One remark involves the reflection that commercial purpose is not always necessary contrary to tax purpose and there is no certainty how the court would differentiate between ordinary commercial transactions and tax avoidance. Case described in the paper with tax haven was held against taxpayer as well as splitting home loans into two parts in order to increase the amount of deductible interest.

In France abuse of law is based on reasonableness and is important judicial tool. Abuse of law takes two main forms: social abuse and intentional abuse aimed to harm a third party. French Cassation Court in the middle of 19th century held that tax administration can not challenge taxpayer's choice of arrangement. Few years later the same court came to the opposite conclusions and recognized the rights of tax administration to examine true substantive nature of the transaction. Para. L 64 of General Tax Code since 1981 (before it was part of Para. 244-1 since 1941) authorized the tax administration to a) disregard a legal act aimed

8 The case involved a scheme designed to take advantage of income-averaging rules that were intended to assist pastoral farmers. A unit trust was established and carried on a modest pastoral farming business. The trust issued shares for AUD 1 to hundreds of university students in order to enable them to enjoy the tax-preferred status of primary producers. The High Court refused to apply Sec. 260 on the basis that adopting the arrangement was a choice open to the taxpayers under the ITAA 1936 (p. 157 in John Prebble and Zoë Prebble and others: Comparing the General Anti-Avoidance Rule of Income Tax Law with the Civil Law Doctrine of Abuse of Law. 2008. Bulletin for International Taxation. s. 151-170) 
to dissimulate income or profit and b) to characterize transaction according to its genuine character. Consultative Committee for Supression of Abuse of Law was established for pre-litigation and burden of proof fell on taxpayer. Since 1963 penalty of $100 \%$ was increased to $200 \%$ for transactions involving abuse of law. Since 1987 also taxpayers could submit the case to the Committee. Burden of proof fall on the party that received negative opinion from the Committee, otherwise on the tax administration. Since 1981 French Conseil d'Etat ruled that abuse of law comprises also cases where 1 . the documents produced by taxpayer are fictious and 2. the documents are not fictious but they cannot be exaplained or justified by any reason other then the exclusive and intentional purpose of reducing or avoiding tax. Sanctions are $80 \%$ increase of tax and parties of abusive transaction are jointly liable for the penalty. Para. L 64 of General Tax Law does not cover all matters, special procedure according to Para. L 64 must be followed strictly when the conditions are met. As to general abuse of law, Conseil d'Etat held in case Janfin that tax administration is entitled to use general abuse of law principle in situations in which Para. L 64 can not be applied. In such a case the tax administration must prove that transaction was fictious. The authors of the article describe also application of Para. L 64 and point to one case in which European Court of Justice concluded that Para. L 64 is compatible with Art. 43 of the EC Treaty. To complete recent development I refer to tax news ${ }^{9}$ and remark that Para. L 64 was amended in 2008 and abuse of law regards all taxes and since 9. 9. 2010 all decisions of tax administration (notices of French tax administrations $13 \mathrm{~L}-9-10,13 \mathrm{M}-2$ and $13 \mathrm{~N}-3-10)$. In 2009 new case-law on abuse of law and dividend tax credits emerged ${ }^{10}$. In two cases Conseil d'Etat denied existence of abuse of law, ruled in favor of taxpayers and suggested that properly structured transactions should be able to withstand a challenge. Tax judges analysed legislative preparatory works and concluded that transaction in question were not in apparent contradiction with the legislator intent. Briefly, critical test was whether owner of the shares was retaining exposure to the economic risk. The fact that the transaction lasted very short period was irrelevant for judges.

However, references on other cases sum up that precedence of EC Treaty and its principle of freedom of establishment is not always in accord with efforts of $\mathrm{EU}$ member states. All members of EU have anti-avoidance rules but in practice they do not determine the scope of their provisions and in many states general abuse of law principle is applied. Anti-avoidance rules deal often cross-border situations and doctrines used in member states are able to couse unjustified restrictions on freedom of establishment. The definiton of „wholly artificial arrangements" was proposed in case of British company Cadbury Schweppes and

9 27/12/10 - France strengthens its provisions combating abuse of law, http://www.wtsf.fr/ en/content/current_tax_news_2572.php, seen 12.10. 2011

$10 \mathrm{http}: / /$ corporate.practicallaw.com/cs/Satellite?blobcol=urldata\&blobheader=application \%2Fpdf\&blobkey=id\&blobtable=MungoBlobs\&blobwhere $=1247266954864 \& s s b i n a r y=\operatorname{tr}$ ue, seen 12.10. 2011 
its subsidiary in Ireland by Advocat-General and ECJ confirmed it. He suggested that existence of tax reduction motive is too subjective criterion for the artificiality of chosen arrangements. The company took into account also level of taxation, like labour costs and infrastructure. There are three criteria to fulfil and if proved, company does not abuses law. Firstly, the subsidiary in question must be genuinely established in the host state a must have substance and capability of performing services that resulted in reducing tax burden. Secondly, the services of the subsidiary must be of genuine nature, its staff must be competent and make real decisions. Thirdly, the subisidiary must have economic value.

The United States with the United Kingdom are regarded as jurisdictions without having an anti-avoidance rule or an abuse of law doctrine (although we could cast doubt on it - as to essence of the issue). What is specific and known in connection with the United States, is compliance with the spirit, used from earliest days of the federal income tax law. Landmark decison of the Supreme Court is from 1935 (Gregory v. Helvering). The court used sham or business purpose doctrine. The sham doctrine is today shortcut phraseoolgy for any number of judicial safeguards - the doctrine of „substance over form“, step transactions, economic substance and business purpose. The situation in the United States changed dramatically in the 1990s, in the time of rise of tax products. Surprisingly, courts favoured far more taxpayers. Test for economic substance must show that taxpayer subjectively had a non-tax purpose for the transaction and that there is objective of a realistic possibility of a pre-tax profit. Issues whether the test is exclusive or should be combined with other factors and whether is disjunctive or conjunctive imply uncertainty. Answers given by courts varied. For relevant case law favouring taxpayers I refer to the paper. Interestingly, none of the recent cases was considered by the Supreme Court on the basis of above mentioned safeguards. Textualism used by the courts coused reactions of the Congress and also its fear that the courts usurpe the role of legislative branch. Congress uses plain language in the law, the courts hardly find in the text intent of legislator and this language permits the taxpayers to receive their benefits. Shift to the responsibility of legislative branch is then observed. They are expected to provide safeguards in the statutes (see case Compaq). Consequently Senate amended tax bill in 2006 to clarify the economic substance doctrine by conjunctive test. Courts then became more restrained in applying these safeguards.

Simultaneously with establishment of Her Majesty Revenue and Customs in 2005 aiming to reduce tax gap „Anti-Avoidance Group“ was set up to systematically and more effectively combat tax avoidance. That means address three main areas: 1 . opportunities to avoid taxes provided by legislation, 2. insufficiency of disincentives or deterrents to prevent taxpayers from avoidance schemes and 3. practical difficulty to identify avoidance transactions quickly. Courts do not recognize sham transactions, however "form over substance" doctrine (or permissive approach) survived until 1980s. Then were courts confrontated with new 
and sophisticated tax avoidance devices a judicial attitudes varied. Purposive approach led to summary called "Less chaos, more uncertainty". That position was compound by the incorporation of EU principle of abuse of law into the United Kingdom VAT law following ECJ's Halifax decision. Author of this paper part notes that it will be fascinating how the developed concept will go beyond VAT borders in other tax areas. I must confirm his concern, refering to Czech case law which I describe later.

Czech tax law is from 1992 based on the doctrine „substance over form“ (dissimulation). In Tax Procedure Code of 1992 Para. 2 al. 7 stipulated that while applying tax laws in tax procedure real content of legal act or other fact crucial for collection or assessment of taxes must be taken into account, if the legal act is hidden by different formal act.

Landmark case regarding dissimulation was decided by the Supreme Administrative Court on 3rd April 2007 (No. 1 Afs 73/2004-89, all decisions are published on www.nssoud.cz in Czech language - but part of information and most important ones are in English). The Court held that there is dissimulation (hiding) when parties to the transaction pretend certain legal act which they do not really intend and hide another legal act which they mean. The key element of application of Para. 7 al. 2 of Tax Procedure Code is to examine relation between intention and demonstration (exercise) of the intent. Obligation of tax administration is to indicate not only ascertained formal situation but also dissimulated real situation and introduce reviewable deliberation leading to the decision including description and consideration of evidence. Dissimulation differs from the circumvention of law when the intention and its demonstration are in accord. The issue is whether dissimulation and abuse of law are different tools. The answer is: yes. Difference is in the intensity of intent of acting parties and also in possibilities of application of abuse of law. Nevertheless, I admit that opinions of various expert may differ and the issue could be more discussed and may also show how tricky, delicate and weak may be both approaches.

According to Czech experts of constitutional law Aleš Gerloch and Jan Tryzna principle of ban on abuse of law resembles principle of ban of exercise of law against good moral. ${ }^{11}$ Authors refer to Czech private case law and conclude that qualification of legal act as abuse of law is rather strict. In contrast with this approach there is decision of the Czech Supreme Administrative Court (of 10. 11. 2005, No. 1 Afs 107/2004 - 48). The facts of the case are as follows: parents of children established non-profit association and through gifts financed sports, cultural and educational activities of their children. Then they deducted these sums from the income tax base. The court held that in these cases must tax administration always consider if this is abuse of law. Court also concluded

11 Gerloch, A., Tryzna, J. Nad vázaností soudce zákonem z pohledu některých soudních rozhodnutí. Právní rozhledy 1/2007, C.H.Beck, Praha (only in Czech language, text is not available on internet) 
that this case does not deal with dissimulation but abuse of law. Gerloch and Tryzna regard the case as interesting due to several reasons. Firstly, the case deals with public law and in that branch principle of legality should be applied unconditionally. The Tax Procedure Code of 1992 did not know the term „abuse of law". Therefore they consider issueable whether court is legitimate to use such an argument (if I follow up this idea, in certain perspective there could be observed abuse of power of the court; the same is valid for tax or other administration). Authors of the paper express objections that abuse of law is institute of private law and that the government (state, tax administration) can not "bully" taxpayers. They also appeal for consistent application of abuse of law if it had been already defined by the Supreme Court in private law. Experts also refer to another case of the Supreme Administrative Court (7 Afs 115/2004) where the argumentation differed and suggested that tax administration can consider the act in question according to its content, not form (dissimulation). Although authors express concerns that freedom of deliberation (and I would watch the same problems in decision-making of administrative bodies), they finally support application of extralegal standards. Jointly, they warn that in such an approach the cases with the same facts and substance could be considered differently. Authors suggest that scope of rules for judicial deliberation should be at least in the Czech Republic stipulated by legislator. Only he is entitled to determine this. Especially in public law the approach to application of abuse of law should be restricitve although to specify unanimous guide is impossible. Authors consider very general scope of rules, as well as very casuistic rules as improper.

Since 2011 new Tax Procedure Code is in force (No. 280/2009 Coll.) and above mentioned principle is stipulated in Para. 8 al. 3: "tax administrator proceeds from real content of legal act or other fact crucial for tax proceedings". I must say that other provisions regarding eventual abuse of law are not incorporated in the code.

Judith Freedman ${ }^{12}$ analyses strenghts and weaknesses of so called principle-based legislation in the times when under influence of European law and judiciary the approach to tax law has been changing. The role of primary and secundary legislation is discussed. The principles in primary legislation can mean legitimate expactations, certainty, equality and proportionality. Judiciary would be safeguard. Principles has higher level then broad or umbiguous rule. Principles have exceptions and they could be in conflict - secondary norms can not be in conflict - always one of them has priority. With principles there is no absence of legitimity both for courts and administration. Some regard principles only as a tool to help for interpretation. If we admit that there are gaps in law, we suppose that intention of lawmaker is not clear and that courts make law. Where

12 Freedman, Judith, Improving (Not Perfecting) Tax Legislation: Rules and Principles Revisited (December 6, 2010). British Tax Review, No. 6, p. 717, 2010; Oxford Legal Studies Research Paper No. 26/2011. Available at SSRN: http://ssrn.com/abstract=1804354 
are principles, there is no gap. This concept can function only if we trust tax administration and judiciary. There is a paradox here: principles-based regulation can give rise to a relationship of trust, but this relationship has to exist for principles-based regulation to be effective (see footnote 24). It is noteworthy that we can not mix principle-based legislation and purposive interpretation of law. In 1969 British judges were criticised for narrow and formalistic interpretation what changed later. British tax administration began to use provisions of the law containing writen purposes (object clauses). In contrast, the principle needs to capture the outcomes in a way that is "intuitive or obvious to someone who understands the law's context". Argument against this concepts shows uncertainty and the fact that it switches the burden from the revenue authority, which must currently show that something is included in the charging provision, to the taxpayer, who must now show that a case is specifically excluded. Lenghty tax and court proceedings help nobody. With use of principle-based regulation would have tax administation issue further legislation and would have less discretion leeway. Australian experiment with principle-based regulation was not entirely successful. The issue is what was the cause. On the other hand, too much discretion entitled to administratuon and courts can lead to discussion on separation of powers and to the question if they are ready to cope with that. Principle-based regulation supplement strategy against tax-avoidance. Some experts believe that application of principle-based legislation would favour tax administration before courts. Concept of principles does not intend to involve morality into tax law. The issue is just to give effect to intention of Parliament. One major problem with using principles is that tax law is very abstract and may not always relate well to the real world, tax law often aims at special groups. Too sophisticated concept led in the past to technical character of tax law and was good basis for tax-avoidance. According to Freedman, associating principle-based legislation with a complex, non-intuitive and highly artificial area and with anti-avoidance legislation, tax administratuon (HMRC) have made this experiment difficult for themselves. Important is to define what is principle a how it is applied. Some indeterminacy is an essential feature of law and the important thing is that the law should provide a guide to the answers. The current route of ever increasing amounts of detailed legislation cannot continue and we need to find ways to improve the situation. The same opinion expressed earlier president of the Czech Supreme Administrative Court Josef Baxa in 2006. ${ }^{13}$

\section{Administrative law and abuse of rights}

As to administrative law, there is one landmark decision of the Czech Supreme Administrative Court regarding procedure on driving offences. The Court held in the Case (of 4. 5. 2011, No. 1 As 27/2011-81) that granting power of attorney to a person from Kuwait is abuse of law. In this case nobody has ever seen that

13 Josef Baxa: What with the surplus of law? Server Aktualne.cz 4. 4. 2006 (in Czech: Tak co s přebytečným právem? http://aktualne.centrum.cz/blogy-a-nazory/clanek.phtml?id=84823 
person, there are doubts if this person even exists and this person is not lawyer (in the Czech Republic there are no qualification requirements for persons representing offenders in administrative proceedings or in court of first instance). The similar cases involved instructed persons from Somalia and similar delivering problems (e.g. the Czech Republic has no bilateral treaty regarding delivering post, or in this countries delivering post lasted reportedly about nine months whereas the term to end offence proceedings for administration is stipulated as one year including coming into force of the decision). Interesting is that above mentioned decision declares right of state to fair process.

In my practice I also met arguments of both parties (claimants and government) of application morality in administrative law. Although some Czech scholars deny this approach, it became reality for parties to the disputes. If my research was exhaustive, there is no decision of the Supreme Administrative Court which has dealt with the issue of morality in administrative law.

\section{Conclusions}

What have all definitions of abuse of law in common? Firstly, it is intent (to get advantage by creating artificial situation). Secondly, we ask how to find it, by subjective or objective criteria, or both, or plus others? It seems that subjective test was completed with objective part. I mentioned above various definitions of abuse of law (rights) which more or less differ. Necessarily I ask, is it at all something new? The answer is: yes and no. There are another concepts - similar or different - and they deal also with extralegal and/or legal standards (morality, good faith; frauds, tax avoidance, tax evasion, dissimiluation, circumvention of law etc.).

According to John and Zoë Prebble, administrations and courts have gone some way towards setting line between legal mitigation and illegal abuse of law. In spite of that effort, there is still considerable uncertainty which constitutes negative feature of general anti-avoidance rule. Nonetheless, concrete rules are the most open to avoidance. The line between tax mitigation and avoidance is fine. Various interests must be balanced and preventing tax avoidance must be addressed in consistent way, predictable and fair so that taxpayers can manage their affairs intelligently, confidently and in good faith. For EU member states balancing is even more complex. They must balance furthermore between their and EU legislation (especially take into account freedom of establishment). Approach of ECJ is formalistic and permissive of tax avoidance. Regardless of existence of provisions containing objective, purpose of statutes (law), this objective is always known (it is to collect taxes). Negative side of purposive approach (or also unlimited general anti-avoidance rule) is that this interpretation would always lead to the result in favour of tax administration. Experts agreed that the lower tax rates and the broader tax base, the less propensity of tax payers to attempt to avoid tax. Some assume that taxpayers are provoked by the tax rates 
and legislation. Still the experience (in the United States) indicates that lowering rates does not lead simply to lowering tax avoidance. Legislation must operate in real world, including political world. Another problem is huge amount of legislative. Contribution of the quoted article can be seen not in proposing effective solution but rather in specifying essential issues.

Michael Byers suggests in his paper on abuse of rights in international law ${ }^{14}$ that the prinicple (of abuse rights) is supplemental to the principle of good faith. I can follow up this idea and suggest that in public law should be abuse of law applied (also) in respect to principle of legitimate expactation. Byers refers to number of scholars who have suggested that unnecessary and extreme but otherwise legal actions taken by a state against its own population, including mass revocations of nationality so as to cause statelessness, could be regarded as abuses of rights. Another area where abuse of rights finds application is with regard to activities that occur outside the territory of any state, in "common spaces" such as the high seas, or in multiple states without any particular territorial nexus, as is the case with the Internet and some sources of pollution. Territory is becoming a less salient feature of the international legal landscape as contemporary problems increasingly reach across and beyond state borders, blurring traditional concepts of sovereignty and responsibility (see page 423-424 of his paper). Byers thinks that in the absence of more specific rules and principles, international courts and tribunals faced with these issues could, and probably should, look to abuse of rights as a general principle of law whose violation in itself constitutes a wrong giving rise to state responsibility and notes that rights may be abused either immediately or prospectively. He serves also with examples of expropriation of property. Author refers to Wolfgang Friedmann's notice that the notions, for example, of "equity, "reasonableness“ or "abuse of rights“ ... do, and are bound to, differ widely. Byers highlights that the rights of states are no longer general and primordial. He expressed this in respect to international law. My question is whether we can say this in connection with application in public law (and abuse of law etc.) inside the national state.

What is imanent to law, each actor's rights are necessarily limited by the rights and interests of others (and also state and society has their rights).

When we regard as crucial intent, then there is resemblance to criminal law. Should we use more principles of criminal law while considering abuse of law? I referred above to several opinions which explain their arguments. To conclude, in many jurisdictions principles like in dubio mitius or interpreation following merely explicitly expressed obligations in public law are applied.

14 Michael Byers: Abuse of Rights: An Old Principle, A New Age. (2002) 47 McGill LJ. 389. http://lawjournal.mcgill.ca/documents/47.2.Byers.pdf 
Unity of legal system is unanimously agreed principle by all experts. Should there be one perception of abuse of law principle? If the Czech Supreme Administrative Court declares that application of abuse of law in administrative (public) law (to be precise - in driving offence cases) must be extraordinary, does it complies with reality of acting of offenders? As Pulkrábek in private law suggests (and derives this from his judicial practice) that abuse of law is found often, and the same applies to reality in public law, how can be (above all in administrative penal law) abuse of law applied as extraordinary tool or ultima ratio? The only way how to deal with this issue is in my opinion to regard abuse of law as ordinary tool or to label the same situation by the same concept, just called not abuse of law and - for example - circumvention of law, dissimulation etc. Difference could by sometimes only rhetorical - strong word just provokes not winning party to the proceedings.

Moreover, there is something else what attacks sometimes hardly found unity of legal order and it is influence of community law - Czech law as any other national laws faces many challenges itself and EC law brings new appeals.

In many areas, it may in practice be impossible to maintain parallel concepts of abuse of right; and we may well see the adoption of the EC concept (or concepts) in the legal systems of some at least of the member states even in areas of the law that are not, de iure, affected by EC law (e.g. tax and administrative law).

Another issue is whether administrative bodies (agencies) are entitled to conclude that in the case was abuse of law? Quoted papers suggest that this issue is dealt chiefly by courts, but example of the United Kingdom or France display that also special units in administrations can address this issue. Same result can be observed in the Czech Republic. In my practice I have judged cases where administration explicitly found abuse of law in driving offence cases, as I described above (but here abuse of law was considered not by special units).

Back to the definiton and features of abuse of law like intent and spirit of the law. In my opinion, decision-maker must have strong sense for and knowledge of reality, fashion of interpretation, avoid formalism and sometimes maybe also judicial and administrative activism. Process is always communication. To have effective process, it is necessary to be confident that we speak the same language and that there are not two or more monologues, this is in my opinion really very important and it is not at all simple to achieve that goal.

Another problem are duality of legal norms (natural and positive), rule of law and general acceptance and position of law and good moral in society and problem of legitimity and quality of decision-makers (in all three powers systems), all these aspect influence justice, fairness and equity.

As Judith Freedman said, a different approach to the way we legislate could both improve the way we think about policy and result in better implementation, application and legitimacy in decision making. Principles-based drafting is not 
a solution to all ills. Nevertheless, it could offer one route, in appropriate cases, to improvement as well as, in other cases, highlighting the need for more fundamental reform. We should not give up this experiment simply because it has not yet delivered total success. No new drafting technique can deliver a perfect (tax) system, but it is worth preserving with principles-based legislation.

I join Lasok and his reference to opinion of Advocate General Tesauro in the Kefalas case who said: "any legal order which aspires to achieve a minimum level of completion must contain self-protection measures... to ensure that the rights it confers are not exercised in a manner which is abusive, excessive or distorted". He also took the view that abuse of right is "a legal concept which certainly has a home, or at least a foundation, in well-established legal systems, but much less so in a legal order like that of the Community, whose evolution towards integration is far from being capable of being considered to be complete". Also the Czech law has still been changing rather dramatically and has been influenced by EC law.

According to Javier Barnes we have administration of third generation which aims the best solution ${ }^{15}$. However, do we know what is the best solution?

According to Richard Posner both the extreme of hyperlegalism and the opposite extreme of a purely discretionary system of justice (and according to me also of administration) are found only in primitive societies. Mature societies mix strict law with discretion. ${ }^{16}$

In my opinion we must not give up efforts and we should weigh various values, to have in mind entirety (holistic approach - that means also to know enough about reality), communicate well and struggle to reach perfection, or at least come closer to it, and this includes to ask relevant questions and try to do our best to find best answers. Recent fragile social situation put challenges on weighing values and parties to the proceedings and administrations and courts face expactations how to bring together legal and social harmony.

15 Prof. Javier Barnes: Towards a Third Generation of Administrative Procedure, in Susan RoseAckerman and Peter L. Lindseth: Comparative Administrative Law. ISBN 9781848446427 , Edward Elgar Publishing Limited 2011

16 Richard Posner: Law and Litarature. 3. edition. Harvard University Press, 2009. p. 570. http://books.google.cz/books?id=Crw04S_5gnUC\&pg=PA163\&lpg=PA163\&dq=hyperle galism\&source=bl\&ots=itbmGr4Gm6\&sig=ZbT_OU9roqtEqvaaCUTRFfYdfQ8\&hl=cs\& $\mathrm{e} i=\mathrm{xhmsToiGJdDMswaA98ngDw \& sa}=X \&$ oi $=$ book_result $\& \mathrm{ct}=$ result \&resnum $=5 \& v e d=0$

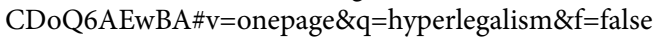

